\title{
Various Methods of Assessing Sugar Beet Seed Vigour and Its Impact on the Germination Process, Field Emergence and Sugar Yield
}

\author{
Sławomir Podlaski ${ }^{1} \cdot$ Chrystian Chomontowski $^{1}$
}

Received: 7 June 2018/Accepted: 16 July 2019/Published online: 6 August 2019

(C) The Author(s) 2019

\begin{abstract}
During 2012-2015, the seed vigour of 54 commercial sugar beet varieties was evaluated. In addition, correlations among different methods of determining seed vigour and the potential impact of low vigour on the quality traits of seeds and root yield were investigated. The chosen seed vigour indicators were field emergence (early and final count), emergence course in a phytotron under controlled conditions (early and final count, mean time of emergence, emergence uniformity) and germination ability under stress conditions regarding substrate moisture and air temperature. The most effective vigour indicators were field and phytotron emergence (early count), mean time of emergence and germination ability under stress conditions. Final field and phytotron emergence constituted weak indicators of seed vigour. Low seed vigour decreased root yield by $3.2 \mathrm{t} / \mathrm{ha}(4.8 \%)$ compared to high seed vigour. Lower yields were caused by slower and less uniform field emergence.
\end{abstract}

Keywords Germination · Emergence · Variability ·

Sugar yield

\section{Introduction}

According to the current International Seed Testing Association (ISTA) definition, seed vigour is the sum of the properties determining the activity and performance of

Chrystian Chomontowski

chrystian_chomontowski@sggw.pl

1 Department of Plant Physiology, Faculty of Agriculture and Biology, Warsaw University of Life Sciences, Warsaw, Poland seed lots for acceptable germination in a wide range of environments (ISTA 2015). The methods of vigour determination have been described by various workers (Heydecker 1972; Caseiro et al. 2004; Powell 2006; McDonald 1993; Dell'Aquila 2009; Mondo et al. 2011; Corbineau 2012). However, the impact of diverse vigour on plant yields has not been well studied. When low vigour leads to reduced crop establishment, it can have a direct effect on yield. In all crops, there is a clear relationship between the number of plants established per unit area and total yield. This relationship is more apparent in crops that cannot compensate by tillering to fill the gaps between the plants (Matthews 1980; Powell 2006). The indirect effect of seed vigour on yield through single plant performance is less known (TeKrony and Egli 1991; Finch-Sawage 1995; Finch-Sawage and Bassel 2016).

The earlier studies indicated that the order of emergence measured by the number of days from the date of sowing until the day of emergence had an enormous influence on plant characteristics (Dürr et al. 1992; Stibbe and Märländer 2002). Sugar beets that emerged first, after 1 month of growth, had a 2.1-9.6 times higher dry matter weight compared to the plants that emerged at the end of the emergence period. The time of emergence was the strongest factor influencing plant weight during harvest in comparison with other factors, such as mean distance to the neighbours in the row and the average weight of the neighbours. Relative growth rate (RGR) was not affected by different dates of emergence (Dürr et al. 1992; Stibbe and Märländer 2002). A constant RGR of plants that emerged late indicated that they are not able to compensate for their shorter vegetation period and accordingly will always contribute less to the dry matter yield of the crop than the plants that emerged early. We may then conclude that the irregularity of emergence dates is the primary 
cause of the variability in the traits of plants in a plantation at the end of the vegetation period.

Much of the progress in seed characteristics, field emergence and early growth improvement has been due to seed crop growth, processing techniques and protecting germinating seedlings with chemicals delivered in pellet form. Further improvement in the speed and spread of emergence was obtained using the seed priming method (Loel et al. 2014). It seems that improvements in the dynamics of field emergence might be another starting point for increased sugar beet yield even if field emergence is at a high level.

Keeping in view the significance of field emergence dynamics for early and final sugar beet yields, the present study was undertaken to determine the mean level of seed vigour of 54 commercial varieties supplied to the Polish market in the years of 2011-2015 by 7 European seed companies: Danisco/Maribo, Syngenta, Strube, KWS AG, Kutno Sugar Beet Breeding Company (KHBC), SESVanderHave and Wielkopolska Sugar Beet Breeding Company (WHBC); the range in the variability of seed vigour during the 5 years of the studies; and the correlations among different methods of determining seed vigour and the potential impact of lower vigour on the quality traits of seeds and root yields.

\section{Materials and Methods}

\section{An Assessment of Mean Seed Vigour, Its Variability, and Correlations Among Different Methods of Vigour Determination}

The studies were conducted in 2011-2015 on 54 commercial seed varieties delivered by 7 seed companies for post-registration variety trials conducted by the Research Centre for Cultivar Testing (COBORU) in Słupia Wielka. Seed samples were randomly collected from the seed lots destined to be sown in different plantations in Poland.

Seed quality was evaluated by three institutions: Research Centre for Cultivar Testing (COBORU), Warsaw University of Life Sciences (WULS) and University of Science and Technology (UTP) in Bydgoszcz.

The Research Centre for Cultivar Testing (COBORU) determined the early and final count of field emergence at 11 experimental stations located in Poland. Both parameters were expressed as percentages and determine the share of the emerged and living plants in relation to the seeds sown. An early count was performed 1 day after the first emergence, while the final count took place 18 days after the first emergence.

At WULS, seed quality evaluation was performed in a phytotron in garden soil with a moisture level of $60 \%$ full water capacity $(\mathrm{FWC})$ and $\mathrm{pH}(\mathrm{KCl}) 6.5$, at a temperature of $10{ }^{\circ} \mathrm{C} \pm 1{ }^{\circ} \mathrm{C}$. The seeds were manually sown at a depth of $2 \mathrm{~cm}$. Each container was equipped with a sensor, monitoring the moisture and soil temperature. Any visible sign of a plant was recorded as a seedling. Seedlings were counted daily and were labelled with sticks. Therefore, we could calculate the ability, speed and uniformity of the emergence during this process. The level of emergence, expressed as a percentage of the seeds sown, was shown with two parameters: early count and final count. The early count was the percentage of the emerged plants 1 day after the commencement of this process, while the final count was the total percentage of the emerged plants in relation to the number of seeds sown.

To assess the emergence speed and spread (uniformity), the Pieper coefficient was used, i.e. the mean time of one plant emergence (MTE) or the average time of emergence spreading. The Pieper coefficient is determined by the following formula:

Pieper coefficient $=\Sigma\left(d_{n} \cdot a_{n}\right) / \Sigma a_{n}$,

where $d_{n}$ is the current emergence day and $a_{n}$ is the current day that relates to the number of emerged plants.

When assessing the speed of emergence, the sowing day is assumed to be the first day of emergence $\left(d_{1}\right)$, while when the spread of emergence is assessed, the assumption is that the first day $\left(d_{1}\right)$ is the day when the first plant emerged from a given seed sample.

In the case of speed and spread of emergence, a higher number indicates slower and more extended emergence.

The assessment of the seed quality of var. Jagusia with differentiated vigour was carried out in the WULS laboratory at $15{ }^{\circ} \mathrm{C}$ on blotting paper at a soil moisture level of $60 \%$ of FWC.

UTP-Bydgoszcz performed an evaluation of laboratory germination at a lowered temperature, 10 and $15{ }^{\circ} \mathrm{C} \pm 1{ }^{\circ} \mathrm{C}$, and a differentiated soil moisture level of $40 \%$ FWC and $60 \%$ FWC of the blotting paper.

\section{The Impact of Varied Seed Vigour on Seed Quality and Root Yields}

Two lots of seeds of the commercial variety Janosik with varied vigour were pelleted according to KHBC technology. The seeds from two lots were evaluated in the WULS laboratory, while plant growth and root yields were determined at three experimental stations in Skierniewice $\left(51^{\circ} 57^{\prime} \mathrm{N}, \quad 20^{\circ} 09^{\prime} \mathrm{E}\right)$, Śmiłów $\left(50^{\circ} 50^{\prime} \mathrm{N}, 21^{\circ} 41^{\prime} \mathrm{E}\right)$ and Straszków $\left(52^{\circ} 15^{\prime} \mathrm{N}, 28^{\circ} 55^{\prime} \mathrm{E}\right)$. Each year, the seeds of the same variety were used. 


\section{Environmental Conditions of Sugar Beet Cultivation}

The soil at Skierniewice was a Stagnic Luvisol, and that at Straszków, a Grey Brown Podzolic. The soil at Śmiłów was classified as a Haplic Luvisol.

The mean annual precipitation for Poland from 1971 to 2000 was $601 \mathrm{~mm}$, while the mean annual temperature was $7.7^{\circ} \mathrm{C}$. From 2011 to 2015 , the mean precipitation for Skierniewice, Straszków and Śmiłów ranged from $448 \mathrm{~mm}$ in 2015 to $605 \mathrm{~mm}$ in 2013, while the temperature ranged from 8.2 in 2013 to 9.6 in 2015. These data indicate that in the years of the research, the average rainfall was lower and the temperature was higher than the multi-year average.

The seeds were sown with a precision drill, every $15 \mathrm{~cm}$ in a row, with $50 \mathrm{~cm}$ between rows. The fertilisation was $140-160 \mathrm{~N}$ without manure, 40-60 $\mathrm{P}$ and $100-125 \mathrm{~K}$, depending on the soil fertility. The size of the plot was $30 \mathrm{~m}^{2}$. The roots were harvested with a combined harvester in mid-October. After the harvest, sugar beets were transported to the laboratory, where the yield and root parameters were evaluated on an automatic Venema line.

One-way analysis of variance and multiple comparisons at a 0.05 probability level were conducted to compare means. The statistical analyses were performed using Statistica 10 (StatSoft). Analysis of correlation and regression (Sokal and Rohlf 1995) was performed to evaluate the relationship between pairs of traits. Asterisks *, ** indicate the value of the correlation coefficients $(r)$ at five and one per cent significance, respectively. The variability of characteristics was determined by calculating the standard deviation of a sample and the coefficient of variation.

\section{Results}

Significant differences in the quality of seeds originating from different companies were recorded with the following traits: field emergence (FE), phytotron plant emergence $(\mathrm{PE})$, early count $(\mathrm{EC})$, mean time to emergence in the phytotron (MTE), final count and germination ability (GA) under temperature and moisture stress conditions (Table 1). The above-mentioned traits were the best indices of seed vigour. The mean emergence uniformity ranged from 2.94 to 4.02 days and was not significantly different. This was due to the high variability of the data throughout the years of the study as well as among the seeds of different varieties from the same company.

Similarly, the average results of final field emergence did not differ significantly among the different companies. Taking into account all nine parameters determining the quality of sugar beet seeds, the worst-quality seeds were supplied by companies $F$ and $G$, while the best were supplied by A and B. Given the high average final field emergence of higher than $80 \%$ and phytotron field emergences higher than $90 \%$, it may be concluded that the seeds of all companies met the quality, determined primarily by seed viability. The differences that occurred simultaneously during the initial emergences and the differences in the speed of phytotron emergence indicate a wide variability of seed vigour.

Taking into account the dynamics of plant emergence in a phytotron, we distinguished three groups from the analysed varieties. These groups had a similar final emergence (92.6-96.7\%) but different rates (Pieper coefficient equal to $10.48-15.35$ days) and uniformity of emergence (3.52-5.18 days) (Fig. 1).

Group 1 included varieties characterised by high final phytotron emergence (96.7\%) and fast (Pieper coefficient equal to 10.48 days) and uniform (3.52 days) emergence. The average emergence $(94.7 \%)$ of Group 2 was similar to that of Group 1, but the emergences were slow and extended in time (13.19 and 5.18 days in comparison with 10.48 and 5.18 days, respectively).

In Group 3, however, the emergence was the slowest (15.35 days), while uniform (4.35 days) values were achieved between the first and second groups.

Farmers need to regularly purchase high-quality seeds characterised by high, stable vigour with small variability in quality among different years of supply across varieties from the same company. Therefore, variability of the traits of seeds offered by different companies is also important for sugar beet growers.

The largest variability of the quality traits of seeds coincided largely with the parameters used to define the best seed vigour (Tables 2, 3). As mentioned earlier, such parameters included early field emergence and sugar beet emergence in the phytotron, the rate of emergence in the phytotron and laboratory seed germination under unfavourable environmental conditions. The largest average coefficients of variability were obtained for the early phytotron emergence (155.1\%-Table 3$)$ and germination ability determined at $10{ }^{\circ} \mathrm{C}$ under optimal moisture conditions of the blotting paper $(139.8 \%$-Table 2$)$. Other traits had a coefficient of variation ranging from 67.6 (emergence uniformity-final count-Table 3) to $88.0 \%$ (field emergence-early count-Table 2 ).

Final emergence, both in the field and in the phytotron, exhibited variability of several percentages. The average differences between the maximum and minimum values for the field and phytotron emergence at the final count were approximately $7.2 \%$ and $13.3 \%$, respectively (Table 3 ). These data showed that, regardless of the level of vigour, final field emergences were similar.

The average value of the trait defining the vigour of the seeds of a given company was correlated with its 
Table 1 Average level of seed vigour, offered on Polish market by seed companies

\begin{tabular}{|c|c|c|c|c|c|c|c|c|c|c|}
\hline \multirow{3}{*}{$\begin{array}{l}\text { Seed } \\
\text { companies }\end{array}$} & \multirow{3}{*}{$\begin{array}{l}\text { Varieties } \\
\text { number }\end{array}$} & \multicolumn{2}{|c|}{ COBORU-FE $(\%)$} & \multicolumn{5}{|c|}{ WULS—phytotron-plant emergence } & \multicolumn{2}{|c|}{ UTP-Bydgoszcz (GA, \%) } \\
\hline & & \multirow[t]{2}{*}{$\mathrm{EC}$} & \multirow[t]{2}{*}{$\mathrm{FC}$} & \multirow[t]{2}{*}{$\mathrm{EC}(\%)$} & \multirow[t]{2}{*}{$\mathrm{FC}(\%)$} & \multicolumn{2}{|c|}{ MTE (days) } & \multirow{2}{*}{$\begin{array}{l}\text { Germination } \\
\text { uniformity } \\
\text { FC (days) }\end{array}$} & \multirow{2}{*}{$\begin{array}{l}\text { Fourth day, } 40 \% \\
\text { FWC, } 15{ }^{\circ} \mathrm{C}\end{array}$} & \multirow{2}{*}{$\begin{array}{l}\text { Sixth day, } 65 \% \\
\text { FWC, } 10{ }^{\circ} \mathrm{C}\end{array}$} \\
\hline & & & & & & $\mathrm{EC}$ & $\mathrm{FC}$ & & & \\
\hline A & 4 & $21.2 \mathrm{~b}$ & 84.0 & $84.7 b$ & $97.2 \mathrm{~b}$ & 10.84 & $10.99 \mathrm{a}$ & 2.66 & $83.6 \mathrm{~cd}$ & $80.5 b c$ \\
\hline B & 12 & $20.8 b$ & 84.1 & $56.2 \mathrm{bc}$ & $96.3 b$ & 10.21 & $12.46 \mathrm{ac}$ & 3.38 & $68.3 \mathrm{bc}$ & $51.5 \mathrm{bcd}$ \\
\hline $\mathrm{C}$ & 4 & $20.2 \mathrm{bc}$ & 82.8 & $70.8 \mathrm{bd}$ & $93.2 \mathrm{a}$ & 11.06 & $11.42 \mathrm{ad}$ & 2.94 & $91.9 \mathrm{~d}$ & $81.6 b c$ \\
\hline $\mathrm{D}$ & 10 & $14.4 \mathrm{ab}$ & 82.7 & $36.2 \mathrm{acd}$ & $94.6 \mathrm{a}$ & 11.53 & $13.41 \mathrm{bc}$ & 3.78 & $46.9 \mathrm{ab}$ & $34.3 \mathrm{ad}$ \\
\hline E & 8 & $13.7 \mathrm{ac}$ & 82.2 & $28.4 \mathrm{ac}$ & $93.5 \mathrm{a}$ & 11.64 & $13.27 \mathrm{bcd}$ & 4.02 & $62.4 \mathrm{~b}$ & $35.1 \mathrm{ad}$ \\
\hline $\mathrm{F}$ & 11 & $11.2 \mathrm{a}$ & 83.5 & $15.8 \mathrm{a}$ & $90.9 \mathrm{a}$ & 11.69 & $13.69 \mathrm{bc}$ & 4.02 & $37.5 \mathrm{a}$ & $14.0 \mathrm{a}$ \\
\hline G & 5 & $10.9 \mathrm{a}$ & 82.8 & $32.1 \mathrm{ac}$ & $94.8 \mathrm{a}$ & 9.27 & $13.65 b c$ & 3.20 & $48.0 \mathrm{ab}$ & $41.8 \mathrm{ad}$ \\
\hline Mean & & 16.06 & 83.2 & 46.3 & $94.4 \mathrm{a}$ & 10.89 & 12.70 & 3.42 & 62.7 & 48.4 \\
\hline LSD $p=0.05$ & & $6.87 * *$ & 2.66 & $36.1 * *$ & $5.38 *$ & 3.12 & $1.86 * *$ & 1.59 & $23.13 * *$ & $33.14 * *$ \\
\hline
\end{tabular}

Different letters denote the difference at $p<0.05$

$F E, E C, F C$ field emergence, early count, final count, respectively, $M T E$ mean time to emergence, $G A$ germination ability

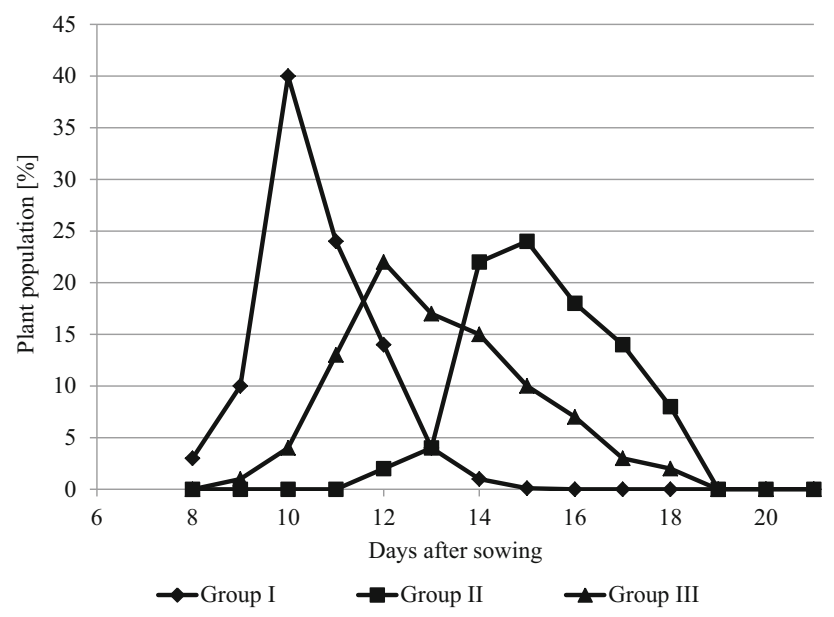

Fig. 1 Dynamics of plant emergence in phytotron

variability throughout the years of the study. Generally, the lower the average vigour of the seeds offered by a company, the higher the variability in the quality of the seeds used in the study. The highest correlation was obtained between the mean phytotron emergence (early count) and the coefficient of variation of this trait (Fig. 2). The regression equation showed that any increase in the mean phytotron emergence by $10 \%$ in the range from 15.8 to $84.7 \%$ was correlated with a decrease in the variability of this trait by approximately $30 \%$.

A large number of methods of seed vigour estimation are based on the application of stress conditions such as low temperature, shortage/excess of water, salinity of the germination substrate, or mechanical resistance for growing seedlings. The results in Table 4 indicate that the final count of field emergences was not significantly correlated with any of the results of the methods of seed vigour assessment. However, the count of field emergences assessed at the beginning of the emergence was most strongly correlated with the phytotron early emergence, mean time to emergence (final count) and germination capacity in the laboratory under conditions of reduced humidity of the blotting paper. The coefficients of determination between these features ranged from 58 to $85 \%$.

The highest correlation between the vigour obtained in the UTP laboratory and phytotron was the mean time to emergence, final count and germination ability under stress conditions of germination (Table 4).

The results obtained for the seed quality shown in Table 5 are highly correlated with the data from Table 1 . The seeds of varying vigour exhibited a similar germination ability after 14 days as the final field emergence. In contrast, the traits that can be regarded as indicators of vigour, mainly concerning the speed of germination and field emergences, were significantly different. Low levels of vigour caused a decrease in root and technological sugar yield by $3.2 \mathrm{t}$ ha and $0.5 \mathrm{t}$ ha, respectively, under the conditions of a very similar plant population.

\section{Discussion}

The results obtained in the present study indicated a high variability in the level of seed vigour and much lower parameters associated with viability, such as the final count in the field or phytotron. Similar results were obtained by Finch-Sawage and Bassel (2016) and other authors (Dürr et al. 1992; Boiffin et al. 1992; Powell 2006). Simultaneously, obtaining a high final count of field and phytotron emergence results, all companies are able to offer the highest-quality seeds to the market. This quality often 
Table 2 Variability of field and laboratory indices of seed vigour

\begin{tabular}{|c|c|c|c|c|c|c|c|c|}
\hline \multirow[t]{3}{*}{ Seed companies } & \multicolumn{4}{|c|}{ COBORU—Field emergence (FE, \%) } & \multicolumn{4}{|c|}{ UTP—Bydgoszcz (GA, \%) } \\
\hline & \multicolumn{2}{|l|}{ Early count } & \multicolumn{2}{|l|}{ Final count } & \multicolumn{2}{|c|}{ Fourth day, $40 \%$ FWC, $15{ }^{\circ} \mathrm{C}$} & \multicolumn{2}{|c|}{ Sixth day, $65 \%$ FWC, $10{ }^{\circ} \mathrm{C}$} \\
\hline & Min/max values & $\mathrm{CV}(\%)$ & Min/max values & $\mathrm{CV}(\%)$ & Min/max values & $\mathrm{CV}(\%)$ & Min/max values & $\mathrm{CV}(\%)$ \\
\hline A & $15.1-28.4$ & 42.7 & $81.5-86.5$ & 4.2 & $65.0-95.8$ & 26.1 & $51.3-96.8$ & 40.0 \\
\hline B & $6.3-36.0$ & 107.5 & $78.5-89.9$ & 9.6 & $3.8-100$ & 99.6 & $0.3-99.8$ & 129.00 \\
\hline $\mathrm{C}$ & $11.2-32.9$ & 80.7 & $77.6-83.9$ & 5.5 & $85.8-99.3$ & 10.4 & $53.8-98.3$ & 40.6 \\
\hline $\mathrm{D}$ & $9.1-21.3$ & 66.0 & $80.1-84.9$ & 4.1 & $15.0-90.8$ & 114.2 & $4.0-85.3$ & 175.7 \\
\hline E & $5.8-20.8$ & 80.9 & $79.4-82.9$ & 3.0 & $19.8-86.0$ & 75.0 & $3.3-65.3$ & 124.8 \\
\hline $\mathrm{F}$ & $2.0-22.0$ & 99.0 & $79.0-88.6$ & 8.1 & $1.0-86.3$ & 160.9 & $1.3-62.0$ & 307.0 \\
\hline $\mathrm{G}$ & $2.1-27.4$ & 139.1 & $78.6-87.8$ & 7.9 & $8-81.8$ & 108.7 & $0.0-95.3$ & 161.4 \\
\hline Mean & & 88.0 & & 6.1 & & 85.0 & & 139.8 \\
\hline
\end{tabular}

Different letters denote the difference at $p<0.05$

$C V$ coefficient of variation

Table 3 Variability of phytotron plant emergence indices

\begin{tabular}{|c|c|c|c|c|c|c|c|c|c|c|}
\hline \multirow[t]{2}{*}{$\begin{array}{l}\text { Seed } \\
\text { companies }\end{array}$} & \multicolumn{2}{|l|}{$\mathrm{EC}(\%)$} & \multicolumn{2}{|l|}{$\mathrm{FC}(\%)$} & \multicolumn{2}{|c|}{ MTE-EC (days) } & \multicolumn{2}{|l|}{ MTE-FC (\%) } & \multicolumn{2}{|c|}{$\begin{array}{l}\text { Emergence uniformity } \\
\text { FC (days) }\end{array}$} \\
\hline & $\begin{array}{l}\text { Min/max } \\
\text { values }\end{array}$ & $\begin{array}{l}\mathrm{CV} \\
(\%)\end{array}$ & $\begin{array}{l}\text { Min/max } \\
\text { values }\end{array}$ & $\begin{array}{l}\mathrm{CV} \\
(\%)\end{array}$ & $\begin{array}{l}\text { Min/max } \\
\text { values }\end{array}$ & $\begin{array}{l}\mathrm{CV} \\
(\%)\end{array}$ & $\begin{array}{l}\text { Min/max } \\
\text { values }\end{array}$ & $\begin{array}{l}\mathrm{CV} \\
(\%)\end{array}$ & $\begin{array}{l}\text { Min/max } \\
\text { values }\end{array}$ & $\begin{array}{l}\mathrm{CV} \\
(\%)\end{array}$ \\
\hline A & $65.5-96.7$ & 25.3 & $91.1-100.0$ & 6.5 & $10.24-11.77$ & 10.0 & $10.40-12.26$ & 12.0 & $1.81-3.55$ & 46.2 \\
\hline B & $0.0-100.0$ & 128.6 & $90.0-100.0$ & 7.3 & $0-12.00$ & - & $10.31-19.99$ & 53.6 & $2.21-6.72$ & 94.4 \\
\hline $\mathrm{C}$ & $12.2-91.1$ & 93.2 & $81.0-100.0$ & 14.4 & $10.00-11.74$ & 11.1 & $10.15-13.67$ & 20.9 & $2.28-3.75$ & 35.4 \\
\hline $\mathrm{D}$ & $0.0-82.2$ & 237.6 & $84.3-98.9$ & 10.9 & $11.00-12.00$ & 6.2 & $11.81-15.02$ & 16.9 & $1.61-6.24$ & 86.5 \\
\hline E & $4.4-82.2$ & 190.6 & $85.6-100.0$ & 10.9 & $10.90-12.00$ & 6.7 & $11.73-15.14$ & 18.2 & $2.45-7.13$ & 82.3 \\
\hline $\mathrm{F}$ & $0.0-63.3$ & 248.1 & $85.5-96.7$ & 8.7 & $0-12.00$ & - & 11.99-16.06 & 21.0 & $2.61-7.68$ & 89.1 \\
\hline $\mathrm{G}$ & $0.0-63.3$ & 162.4 & $83.3-97.8$ & 10.8 & $0-11.97$ & - & $11.61-15.35$ & 19.3 & $2.26-4.03$ & 39.1 \\
\hline Mean & & 155.1 & & 9.9 & & & & 23.1 & & 67.6 \\
\hline
\end{tabular}

Minimal values $=0$

depends on the seed policy of each company; this is determined by the size of the market, the average price of seeds, the significance of the market for the interests of the company and the level of agriculture (Podlaski et al. 2015).

Progress in sugar beet seed processing resulted in the fact that there were no significant differences in the final count among different seed lots during the assessments carried out in the phytotron or under field conditions. This observation is contradictory to the common view that final field emergence and seedling establishment are indicators of seed vigour (Powell 2006; Finch-Sawage and Bassel 2016).

It should be recalled that in Europe, sugar beet seeds are produced in Po Valley in Italy and southern France, where there are good conditions for obtaining seeds of high quality. In addition, during seed processing, only $20 \%$ of the harvested raw seeds are pelleted.

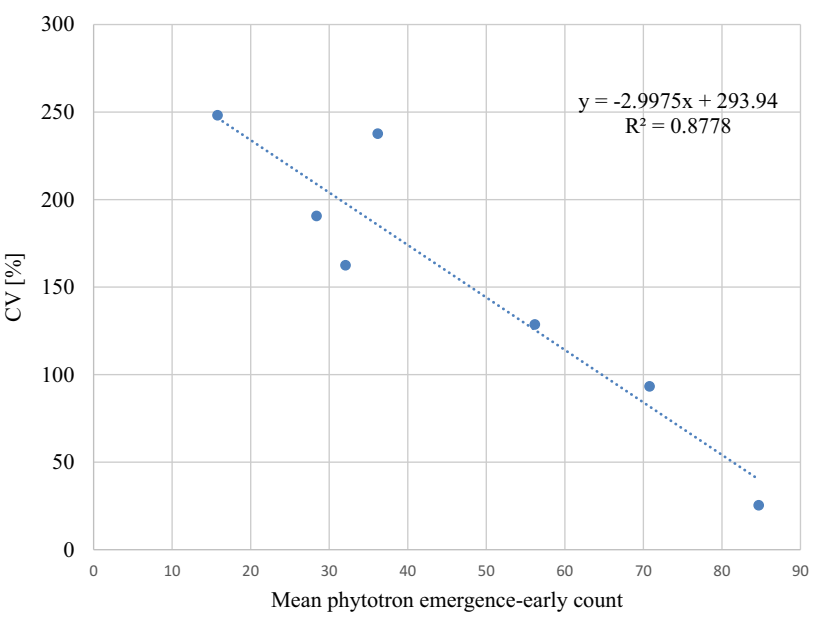

Fig. 2 Relationship between mean phytotron field emergence and variability of emergence for seeds from the seven companies 
Table 4 Correlation of pairs of matrix between different qualitative traits of sugar beet seeds

\begin{tabular}{|c|c|c|c|c|c|c|c|c|c|c|}
\hline \multirow[t]{3}{*}{ Traits } & & \multicolumn{2}{|c|}{$\begin{array}{l}\text { COBORU-FE } \\
(\%)\end{array}$} & \multicolumn{5}{|c|}{ SGGW-phytotron emergence (\%) } & \multicolumn{2}{|c|}{ UTP-Bydgoszcz (GA, \%) } \\
\hline & & \multirow[t]{2}{*}{$\mathrm{EC}$} & \multirow[t]{2}{*}{$\mathrm{FC}$} & \multirow[t]{2}{*}{$\mathrm{EC}$} & \multirow[t]{2}{*}{ FC } & \multicolumn{2}{|c|}{ MTE (days) } & \multirow{2}{*}{$\begin{array}{l}\text { Uniformity } \\
\text { FC (days) }\end{array}$} & \multirow{2}{*}{$\begin{array}{l}\text { Fourth day, } \\
40 \% \\
\text { FWC, } 15{ }^{\circ} \mathrm{C}\end{array}$} & \multirow{2}{*}{$\begin{array}{l}\text { Sixth day, } \\
65 \% \\
\text { FWC } 10^{\circ} \mathrm{C}\end{array}$} \\
\hline & & & & & & EC & FC & & & \\
\hline \multirow[t]{2}{*}{$\begin{array}{l}\text { COBORU } \\
\text { FE }(\%)\end{array}$} & EC & - & 0.054 & $0.923 * *$ & 0.572 & 0.381 & $-{ }^{-} .903 * *$ & $-0.759^{*}$ & $0.846 * *$ & $0.760 *$ \\
\hline & FC & 0.054 & - & -0024 & 0.439 & -0.042 & 0.116 & -0.101 & -0.389 & -0.399 \\
\hline \multirow[t]{5}{*}{$\begin{array}{l}\text { SGGW } \\
\text { PE (\%) }\end{array}$} & EC & $0.923 * *$ & -0.024 & - & 0.583 & 0.325 & - & $-0.783^{*}$ & $0.844 * *$ & $0.846 * *$ \\
\hline & FC & 0.572 & 0.439 & 0.583 & - & 0.005 & -0.439 & $-0.756^{*}$ & 0.275 & 0.107 \\
\hline & MTE, EC days & 0.381 & -0.042 & 0.325 & 0.005 & - & -0.435 & 0.136 & 0.348 & 0.437 \\
\hline & MTE, FC, days & $0.903 * *$ & 0.116 & $-0.979 * *$ & -0.439 & -0.435 & - & 0.681 & $-0.891 * *$ & $-0.914 * *$ \\
\hline & Uniformity FC, days & $-0.759^{*}$ & -0.101 & $-0.783^{*}$ & $-{ }^{-} .756^{*}$ & 0.136 & $0.681 *$ & - & -0.625 & -0.418 \\
\hline \multirow[t]{2}{*}{$\begin{array}{l}\text { UTP } \\
\text { GA }(\%)\end{array}$} & $\begin{array}{l}\text { Fourth day, } 40 \% \text { FWC } \\
15^{\circ} \mathrm{C}\end{array}$ & $0.846 * *$ & -0.389 & $0.844 * *$ & 0.275 & 0.348 & $-{ }^{0.891 * *}$ & -0.625 & - & $0.877 * *$ \\
\hline & $\begin{array}{l}\text { Sixth day, } 65 \% \text { FWC, } \\
10{ }^{\circ} \mathrm{C}\end{array}$ & $0.760^{*}$ & -0.399 & $0.846 * *$ & 0.107 & 0.437 & - & -0.418 & $0.877 * *$ & - \\
\hline
\end{tabular}

$F E, E C, F C$ field emergence, early count, final count, respectively, $M T E$ mean time to emergence, $G A$ germination ability

*Relevant to $p>0.05$; **Relevant to $p>0.01$

Table 5 Effect of seed vigour level on germination, field emergence course and yield of sugar

\begin{tabular}{|c|c|c|c|}
\hline \multirow[t]{2}{*}{ Plant traits } & \multirow[t]{2}{*}{ Units } & \multicolumn{2}{|c|}{ Vigour level } \\
\hline & & High & Low \\
\hline Germination ability, 4 th day, $15^{\circ} \mathrm{C}$ & $\%$ & $52.3 b$ & $17.0 \mathrm{a}$ \\
\hline Mean time to germination after 4 days at $15^{\circ} \mathrm{C}$ & days & $3.74 \mathrm{a}$ & $3.99 \mathrm{~b}$ \\
\hline Germination ability, 14 th day, $15^{\circ} \mathrm{C}$ & $\%$ & 91.2a & 92.2a \\
\hline Mean time to germination, after 14 days at $15{ }^{\circ} \mathrm{C}$ & days & $4.54 \mathrm{a}$ & $5.34 \mathrm{~b}$ \\
\hline Field emergence-final count & $\%$ & 79.8a & $78.5 \mathbf{a}$ \\
\hline Mean time to emergence & days & $12.32 \mathrm{a}$ & $12.74 b$ \\
\hline Plant population & $0.000 / \mathrm{ha}$ & $100.2 \mathrm{a}$ & $99.8 \mathbf{a}$ \\
\hline Roots yield & t/ha & $67.3 b$ & $64.1 \mathrm{a}$ \\
\hline Sugar content & $\%$ & $18.3 b$ & $18.0 \mathrm{a}$ \\
\hline Technological sugar yield & $\mathrm{t} / \mathrm{ha}$ & $10.8 \mathrm{~b}$ & $10.3 \mathrm{a}$ \\
\hline
\end{tabular}

Commercial variety Janosik; means from 3 years and 3 places of growth estimation

Different letters denote the difference at $p<0.05$

Presented studies have shown that the best method to assess seed vigour is a phytotron assessment performed in the soil at $\pm 10{ }^{\circ} \mathrm{C}$. This method allows for the achievement of the highest correlation coefficient of $r=0.923^{* *}$ between field emergence and phytotron emergence (early count.) In addition, it is the only method that allows the evaluation of four parameters of seed quality: ability, speed, uniformity of emergences, and plant losses during post-emergence time. In Europe, the sugar industry accepted the results of vigour tests performed by the 
Belgian Sugar Beet Research Institute (IRS), which were conducted in a compost/sand mix at a constant $10{ }^{\circ} \mathrm{C}$ for 17 days (Stevens 2013).

Differences in root yield of seeds with varying vigour are not determined by plant emergence ability, but result from the differences in emergence time and uniformity. These differences tend to diminish later during crop development, but as research has shown, their effect lasts until harvest (Stibbe and Märländer 2002). The impact of low uniformity of emergence is the most significant in the case of vegetable crops, where marketable yield is more important than biological yield (TeKrony and Egli 1991; Finch-Sawage and Bassel 2016).

\section{Conclusions}

In conclusion, the final field and phytotron emergences in soil at $10{ }^{\circ} \mathrm{C}$ are weak indicators of sugar beet seed vigour. The most complete information about seed vigour can be determined by assessing the emergence rate expressed by field emergence (early count) or by phytotron mean time to emergence (final count). Differences in roots and sugar yields among plantations of the same variety with a similar plant population, grown under similar agro-ecological conditions, result from the differences in the speed and uniformity of the emergences.

Acknowledgements In our publication we partly used results obtained from scientific grant number PBS 1/A8/15/2013, financed by the Ministry of Science and Higher Education of the Republic of Poland. We thank the Research Centre for Cultivar Testing in Słupia Wielka and University of Science and Technology (UTP) in Bydgoszcz for allowing the use of research results obtained in Post-registration Sugar Beet Variety Testing.

\section{Compliance with Ethical Standards}

Conflict of interest The authors declare that they have no conflict of interest.

Human and Animals Rights Authors declare no research involving human participants and/or animals was conducted.

Open Access This article is distributed under the terms of the Creative Commons Attribution 4.0 International License (http://creativecommons.org/licenses/by/4.0/), which permits unrestricted use, distribution, and reproduction in any medium, provided you give appropriate credit to the original author(s) and the source, provide a link to the Creative Commons license, and indicate if changes were made.

\section{References}

Boiffin, J., C. Dürr, A. Fleury, A. Marin-Lafleche, and I. Maillet. 1992. Analysis of the variability of sugar beet (Beta vulgaris L.) growth during the early stages. Agronomy 12: 515-525.

Caseiro, R., M.A. Bennett, and J. Marcos-Filho. 2004. Comparison of three priming techniques for onion seed lots differing in initial seed quality. Seed Science and Technology 32(2): 365-375.

Corbineau, F. 2012. Markers of seed quality. Seed Science Research 22: $561-568$.

Dell'Aquila, A. 2009. Development of novel techniques in conditioning testing and sorting seed physiological quality. Seed Science and Technology 37: 608-624.

Dür, C., J. Boiffin, A. Fleury, and L. Coulomb. 1992. Analysis of the variability of sugar beet (Beta vulgaris) growth during the early stages. Agronomy 12: 527-535.

Finch-Sawage, W.E. 1995. Influence of seed quality on crop establishment, growth and yield. In Seed quality: Basic mechanisms and agricultural implications, ed. A.S. Basra, 361-384. New York: Haworth Press.

Finch-Sawage, W.E., and G.W. Bassel. 2016. Seed vigour and crop establishment extending performance beyond adaptation. Journal of Experimental Botany 67(3): 567-591.

Heydecker, W. 1972. Seed ecology: Proceedings. Pennsylvania State: University Press.

Loel, J., C. Kenter, B. Märländer, and C.M. Hofmann. 2014. Assessment of breeding progress in sugar beet by testing old and new varieties under greenhouse and field conditions. European Journal of Agronomy 52: 146-156.

McDonald, M.B. 1993. The history of seed vigour testing. Journal of Seed Technology 17: 93-101.

Matthews, S. 1980. Controlled deterioration: A new vigour test for crop seeds. In Seed production, ed. P.D. Hebblethwaite, 647-660. London: Butterworths Press.

Mondo, V.H.V., M.A.N. Dias, and M.B. McDonald. 2011. Seed vigor imaging system for two-day old corn seedling evaluation. Seed Technology 33: 191-196.

Podlaski, S., Z. Chrobak, H. Wzorek, and D. Gozdowski. 2015. Quality assessment of seeds offered on the polish market and effect of seed vigour on root yield of sugar beet. Electronic Journal of Polish Agricultural Universities 18(1): 1-7.

Powell, A.A. 2006. Seed vigour and its assessment. In Handbook of seed science and technology, ed. A.S. Basra, 603-648. New York: Haworth Press.

Sokal, R.R., and F.J. Rohlf. 1995. Biometry: The principles and practice of statistics in biological research, 3rd ed. New York: W.H. Freeman and Co.

Stevens, M. 2013. Emergence issue-A review by the BBRO. British Sugar Beet Review 81(4): 13-18.

Stibbe, C., and B. Märländer. 2002. Field emergence dynamics significance to intraspecific competition and growth efficiency in sugar beet (Beta vulgaris L.). European Journal of Agronomy 3: $161-171$.

TeKrony, D.M., and D.B. Egli. 1991. Relationship of seed vigor to crop yield: A review. Crop Science 31: 816-822.

Publisher's Note Springer Nature remains neutral with regard to jurisdictional claims in published maps and institutional affiliations. 